\title{
Animasi Interaktif Sebagai Media Pembelajaran Bahasa Inggris Menggunakan Metode ADDIE
}

\author{
Mia Rosmiati \\ Program Studi Sistem Informasi \\ Fakultasi Teknologi Informasi, Universitas Bina Sarana Informatika \\ e-mail: mia.mrm@bsi.ac.id
}

Cara Sitasi: Rosmiati, M. (2019). Animasi Interaktif Sebagai Media Pembelajaran Bahasa Inggris Menggunakan Metode ADDIE. Paradigma - Jurnal Komputer dan Informatika, 21(2), 261-268. doi:10.31294/p.v21i2.6019

\begin{abstract}
English is an international standard language used in conversations between countries. Therefore, learning English is very important given to children from an early age. However, in its implementation there are still many children who have difficulty learning English using learning methods that are difficult, less interesting and difficult. This learning media only relies on stationery such as books, paper, and pencils so that children increasingly like the learning process. Nowadays there are various interesting ways to attract children's interest in learning. One step that can be taken is to use computer technology as a medium for learning English for communication material with audio and visual material. Interactive animation is one form of learning method that uses audio visual media. In the world of education, animation has a role as a learning media that is quite interesting. Animation can increase interest in learning and understanding of certain fields of science. In addition, animation can also facilitate teachers in the learning process and also delivery material for students.
\end{abstract}

Keywords: English, Interactive Animation, Learning Media

\section{PENDAHULUAN}

Bahasa inggris merupakan bahasa internasional yang menjadi standar bahasa yang digunakan dalam berkomunikasi antar negara. Karenanya pendidikan Bahasa Inggris tidak bisa diremehkan kehadirannya. Di zaman sekarang ini banyak orangtua yang telah mempersiapkan anak-anak mereka untuk fasih berbahasa Inggris sejak dini, karena kemampuan berbahasa Inggris sangat diperlukan di masa ini dan di masa yang akan datang. Banyak lembaga-lembaga pendidikan untuk anak usia dini yang sudah mulai mengenalkan pembelajaran bahasa inggris kepada anak didiknya.

Namun, pada kenyataannya banyak kendala di mana seorang anak ternyata pada akhirnya masih belum menguasai bahasa inggris dengan lancar meskipun proses pembelajarannya sudah dilakukan pada usia dini. Saat ini pelajaran bahasa inggris masih kurang banyak diminati siswa, dan banyak dinilai siswa merupakan salah satu pelajaran yang cukup sulit. Hal ini disebabkan adanya beberapa faktor diantaranya metode pengajaran yang dilakukan masih kurang menarik dan kurang variatif, serta minat siswa yang masih sangat rendah.

Dalam dunia pendidikan suatu metode pembelajaran dapat dihadirkan dengan menggunakan alat peraga pembelajaran atau sering dikenal media pembelajaran. Namun terkadang alat peraga yang digunakan masih kurang menarik dikarenakan kurang interaktif dan monoton. Salah satu metode pembelajaran yang sekarang ini dapat dikembangkan adalah dengan memanfaatkan teknologi komputer, sebagai media pembelajaran ini dapat menyampaikan materi pembelajaran secara tekstual, audio maupun visual (Ariyati \& Misriati, 2016).

Animasi interaktif merupakan salah satu bentuk metode pembelajaran yang menggunakan media audio visual. Dalam dunia pendidikan, animasi memiliki peran sebagai media pembelajaran yang cukup menarik. Animasi dapat meningkatkan minat belajar dan pemahaman terhadap suatu bidang ilmu tertentu. Selain itu animasi juga dapat mempermudah guru dalam proses pembelajaran dan pengajaran serta penyampaian materi kepada siswa. Dengan adanya media pembelajaran animasi interaktif siswa dapat belajar lebih tertarik dan menarik dalam proses pembelajaran bahasa inggris serta adanya animasi interaktif siswa bisa membaca dengan baik dan benar (Wijayanto, 2014).

Berdasarkan latar belakang masalah di atas, maka identifikasi masalah dalam penelitian ini yaitu:

1. Terbatasnya pembelajaran yang menggunakan animasi interaktif.

2. Anak-anak merasa jenuh dengan media pembelajaran yang monoton seperti halnya dengan membaca buku paket. 
3. Kurangnya media pembelajaran pendukung di sekolah dan hanya mendengarkan penjelasan dari guru.

Sedangkan perumusan masalah dalam penelitian ini adalah:

1. Bagaimana membuat media edukasi animasi interaktif untuk membantu memudahkan guru dan anak dalam proses belajar bahasa inggris?

2. Bagaimana cara membuat media pembelajaran yang dapat membantu anak untuk mudah mengingat pelajaran sehingga proses belajar mengajar menjadi efektif dan menyenangkan?

3. Bagaimana cara membuat media pembelajaran yang bisa diakses dimana saja di zaman yang teknologinya semakin berkembang seperti saat ini?

\section{METODOLOGI PENELITIAN}

Penelitian ini dilakukan untuk mendapatkan data dan informasi yang akurat mengenai proses belajar mengajar untuk dianalisa sehingga dapat diketahui kelemahan atau kekurangan dalam pembelajaran. Adapun metode penelitian yang digunakan dalam penelitian ini antara lain :

\section{Teknik Pengumpulan Data}

a. Observasi

Metode Pengamatan secara langsung atau observasi dilakukan dengan mengamati proses pembelajaran bahasa inggris di PAUD AlHidayah, sehingga dapat diketahui proses yang berjalan dan kebutuhan siswa serta guru dalam proses pembelajaran bahasa inggris.

b. Wawancara

Metode wawancara dilakukan dengan melakukan tanya jawab kepada pihak-pihak yang terkait dalam proses pembelajaran secara langsung seperti guru, siswa, dan juga orang tua

c. Studi Pustaka

Metode studi pustaka dilakukan dengan mengumpulkan informasi atau referensi mengenai topik terkait melalui buku-buku, artikel ilmiah dalam jurnal, e-book dan internet.

\section{Metode Pengembangan Perangkat Lunak}

Berdasarkan permasalahan yang sudah dijelaskan sebelumnya, maka dalam penelitian ini akan dihasilkan sebuah sebuah produk media pembelajaran. Menurut (Sugiyono, 2013) metode penelitian dan pengembngan merupakan metode penelitian yang digunakan untuk menghasilkan suatu produk tertentu dan menguji keefektifan produk tersebut.

Prosedur penelitian ini mengadaptasi model pengembangan ADDIE yang terdiri dari lima tahapan yang meliputi analisis (analysis), desain (design), pengembangan (development), implementasi (implementation) dan evaluasi (evaluation) (Sugiyono, 2015).

Model ADDIE terdiri dari 5 komponen yang saling berkaitan dan terstruktur secara sistematis yang artinya dari tahapan yang pertama sampai tahapan yang kelima dalam pengaplikasiannya harus secara sistematik dan tidak bisa diurutkan secara acak. Kelima tahap atau langkah ini sangat sederhana jika dibandingkan dengan model desain yang lainnya. Sifatnya yang sederhana dan terstruktur dengan sistematis maka model desain ini mudah dipahami dan diaplikasikan.

Adapun langkah penelitian pengembangan ADDIE dalam penelitian ini jika disajikan dalam bentuk bagan di bawah ini:

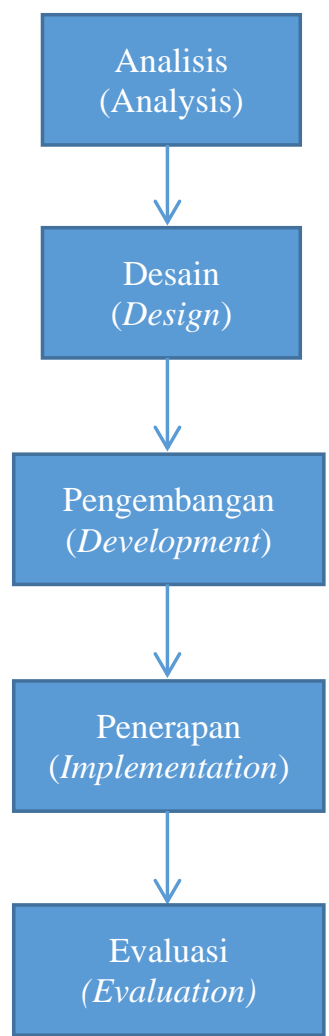

Sumber : (Sugiyono, 2015)

Gambar 1. Langkah-langkah model pengembangan ADDIE

Langkah-langkah model pengembangan ADDIE :

a. Analisis (Analysis)

Melakukan analisis kebutuhan materi animasi, karakteristik siswa, analisis perangkat lunak dan analisis spesifikasi.

b. Desain (Design)

Terdiri dari pembuatan storyboard animasi, penyusunan materi dan soal evaluasi, pembuatan latar belakang media (background), gambar dan tombol pada aplikasi.

c. Pengembangan (Development)

Terdiri dari pembuatan media animasi interaktif, validasi media dan revisi media.

d. Penerapan (Implementation) 
Merupakan tahap uji coba media.

e. Evaluasi (Evaluation)

Melakukan perbaikan produk berdasarkan uji coba lapangan dan pembuatan produk akhir berupa CD-ROM Multimedia interaktif terhadap produk yang dikembangkan.

\section{HASIL DAN PEMBAHASAN}

1. Analisis (Analysis)

Animasi interaktif pembelajaran bahasa inggris ini ditujukan untuk anak-anak usia dini di PAUD AlHidayah. Berdasarkan observasi dan wawancara yang telah dilakukan didapatkan analisis kebutuhan untuk pengguna animasi yaitu dibutuhkan adanya animasi yang dapat mengenalkan bahasa inggris seperti jenis-jenis huruf, jenis-jenis angka, jenisjenis kendaraan dan jenis-jenis hewan, serta adanya soal-soal berupa kuis yang dapat dijadikan sebagai games untuk anak-anak.

Selain kebutuhan sistem, dalam perancangan animasi interaktif ini juga dibutuhkan serangkaian peralatan untuk mendukung kelancaran proses pembuatan dan pengujian pembelajaran animasi interaktif. Berikut aspek-aspek yang dibutuhkan dalam pembuatan pembelajaran animasi interaktif.

a. Analisis Kebutuhan Perangkat Lunak

Tabel 1. Kebutuhan Perangkat Lunak

\begin{tabular}{|c|c|}
\hline Kebutuhan & Keterangan \\
\hline Windows 7 & Sebagai sistem operasinya \\
\hline $\begin{array}{l}\text { Adobe } \\
\text { FlashCS6 }\end{array}$ & $\begin{array}{llr}\text { Sebagai } & \text { Aplikasi } & \text { pembuatan } \\
\text { animasi } & \text { dalam } & \text { pembelajaran } \\
\text { animasi interaktif. } & \end{array}$ \\
\hline $\begin{array}{l}\text { Adobe } \\
\text { photoshop CS6 }\end{array}$ & $\begin{array}{lrr}\text { Aplikasi } & \text { pendukung } & \text { untuk } \\
\text { pengolahan } & \text { gambar } & \text { dalam } \\
\text { pembelajaran } & \text { animasi interaktif }\end{array}$ \\
\hline $\begin{array}{lll}\text { Cool Edit Pro } \\
2.1\end{array}$ & $\begin{array}{lrr}\text { Aplikasi } & \text { pendukung } & \text { untuk } \\
\text { pengolahan } & \text { suara } & \text { dalam } \\
\text { pembelajaran animasi interaktif. }\end{array}$ \\
\hline
\end{tabular}

\section{b. Analisis Kebutuhan Perangkat Keras}

Tabel 2. Kebutuhan Perangkat Keras

\begin{tabular}{ll}
\hline \multicolumn{1}{c}{ Kebutuhan } & \multicolumn{1}{c}{ Keterangan } \\
\hline Processor & Intel(R) Coleron(R) CPU 1007U @ \\
& $1.50 \mathrm{GHz}$ (2 CPUs-1,5GHz \\
\hline Memory & $4096 \mathrm{MB} \mathrm{RAM}$ \\
\hline Hardisk & $500 \mathrm{~GB}$ \\
\hline Monitor & Standart 12” \\
\hline
\end{tabular}

Sumber : Hasil Penelitian (2019)

\section{Desain (Design)}

Perancangan tampilan diperlukan untuk mengolah informasi dan memberikan kemudahan bagi pengguna sehingga mudah dimengerti oleh pengguna. Dengan demikian dengan perancangan tampilan dapat memberikan informasi yang sesuai dengan tujuan yang akan dicapai. Desain merupakan penggambaran perencanaan dan pembuatan sketsa atau pengaturan dari beberapa elemen yang terpisah ke salah satu kesatuan yang utuh dan mempunyai fungsi. Perancangan storyboard animasi interaktif pembelajaran bahasa inggris dimulai dengan:

a. Storyboard Menu Utama

Storyboard menu utama adalah tampilan menu utama untuk memilih jenis pembelajaran animasi interaktif dengan rancangan sebagai berikut:

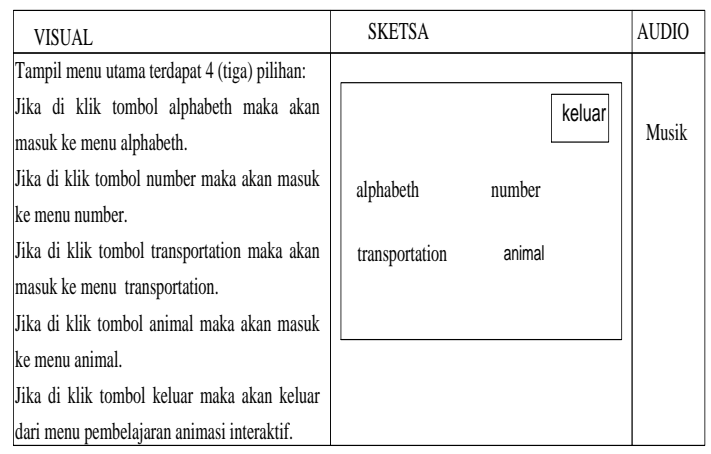

Sumber : Hasil Penelitian (2019)

Gambar 2. Storyboard Menu Utama

\section{b. Storyboard Alphabeth}

Storyboard Alphabeth adalah tampilan alphabeth dengan rancangan sebagai berikut:

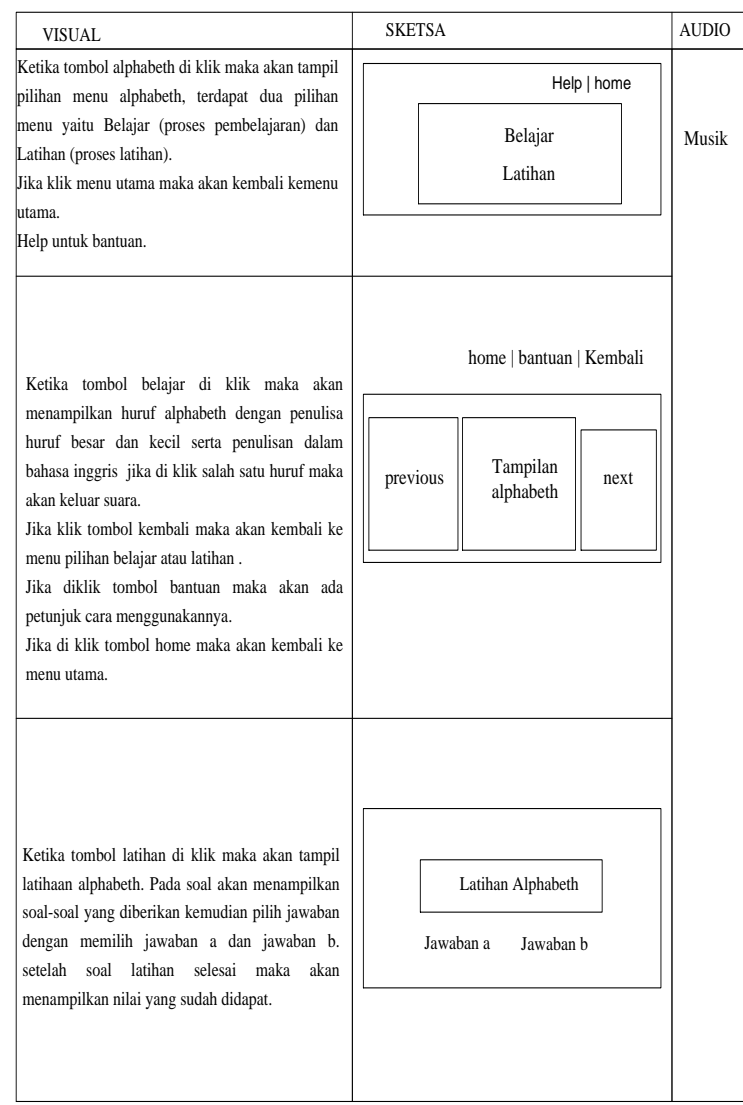

Sumber : Hasil Penelitian (2019)

Gambar 3. Storyboard Alphabeth

c. Storyboard Number

Storyboard Number adalah tampilan number dengan 
perancangan sebagai berikut:

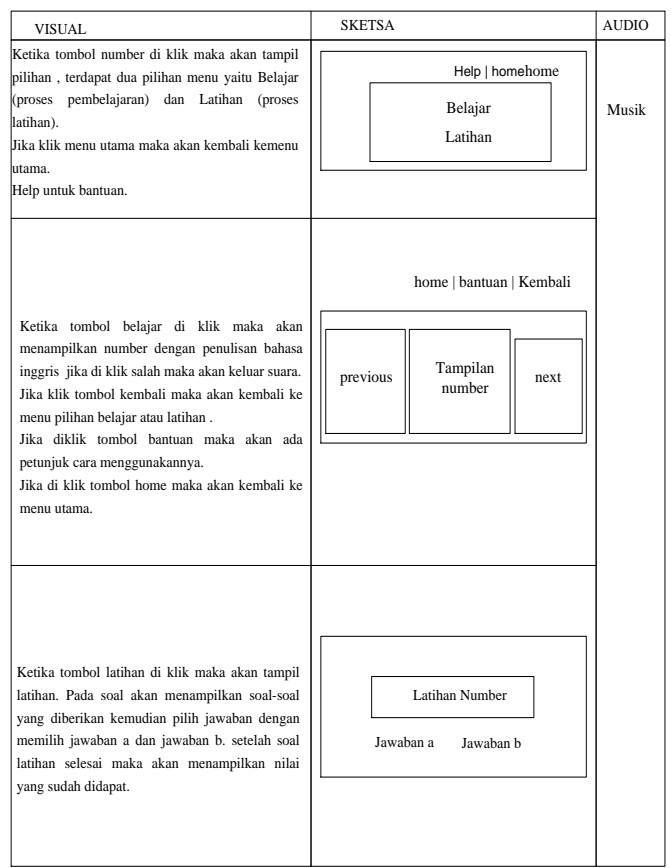

Sumber : Hasil Penelitian (2019)

Gambar 4. Storyboard Number

\section{d. Storyboard Transportation}

Storyboard Transportation adalah tampilan transportation dengan perancangan sebagai berikut:

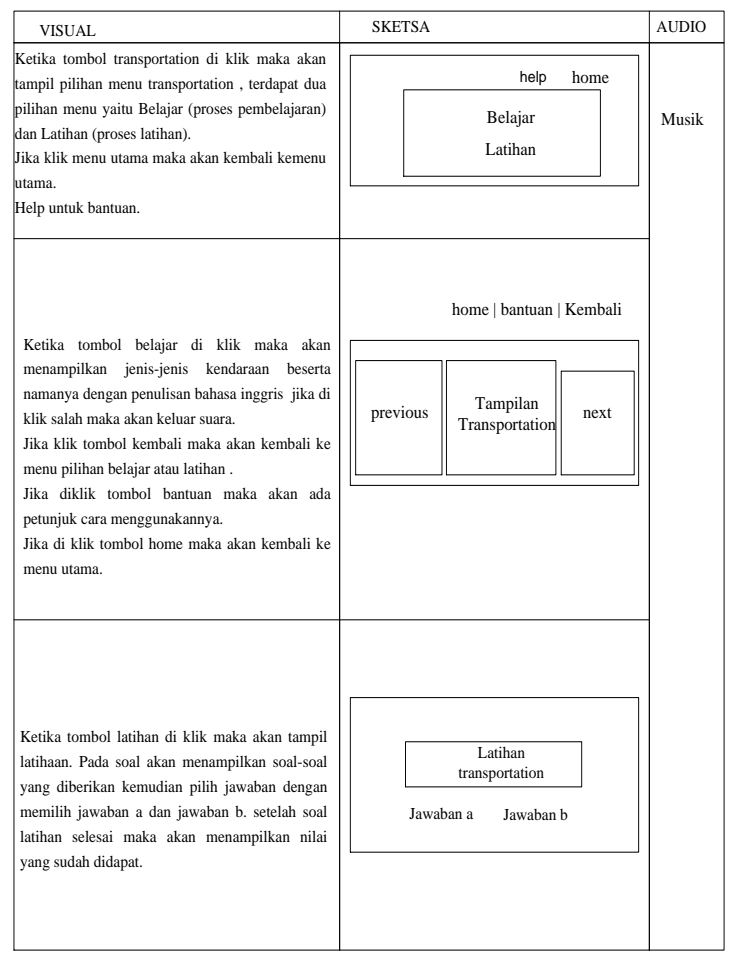

Sumber : Hasil Penelitian (2019)

Gambar 5. Storyboard Transportation

\section{e. Storyboard Animal}

Storyboard Animal adalah tampilan animal dengan perancangan sebagai berikut:

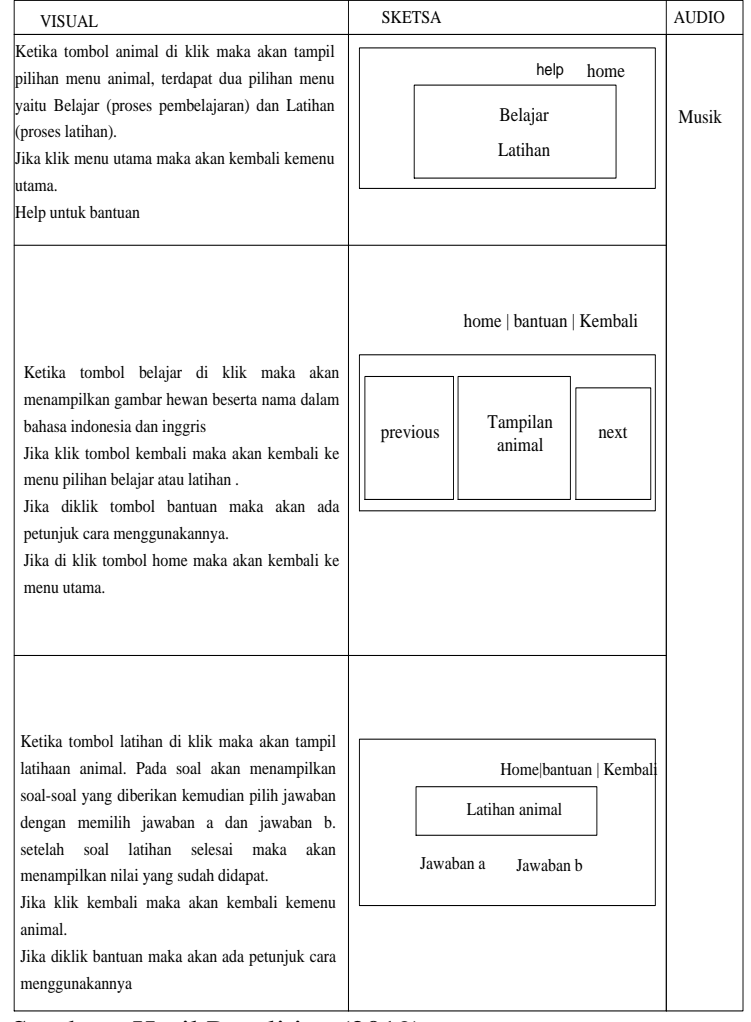

Sumber : Hasil Penelitian (2019)

Gambar 6. Storyboard Animal

3. Pengembangan (Development)

Menjelaskan pembangunan rancangan antar muka (interface) yang terdapat pada animasi interaktif pembelajaran bahasa inggris untuk anak-anak. Tampilan antar muka pada program pembelajaran bahasa inggris untuk anak-anak berdasarkan hasil rancangan antar muka.

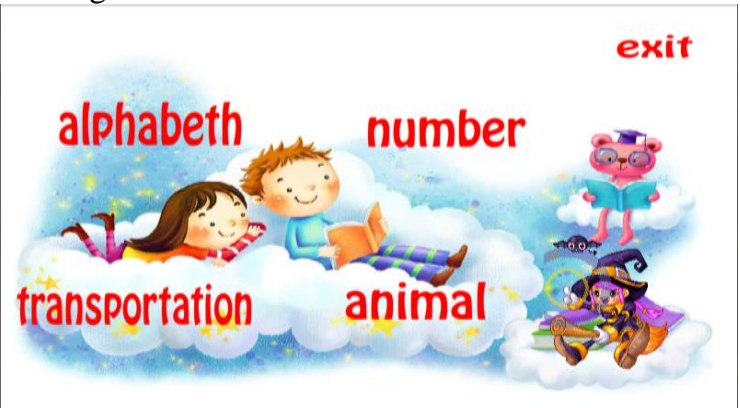

Sumber : Hasil Penelitian (2019)

Gambar 7. Tampilan Menu Utama

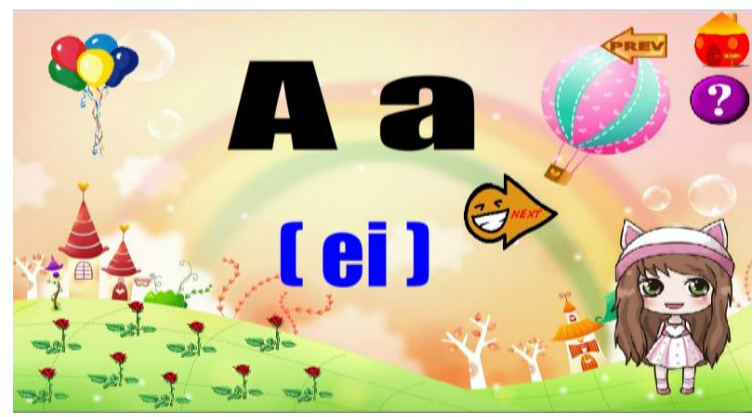

Sumber : Hasil Penelitian (2019)

Gambar 8. Tampilan Alphabeth 


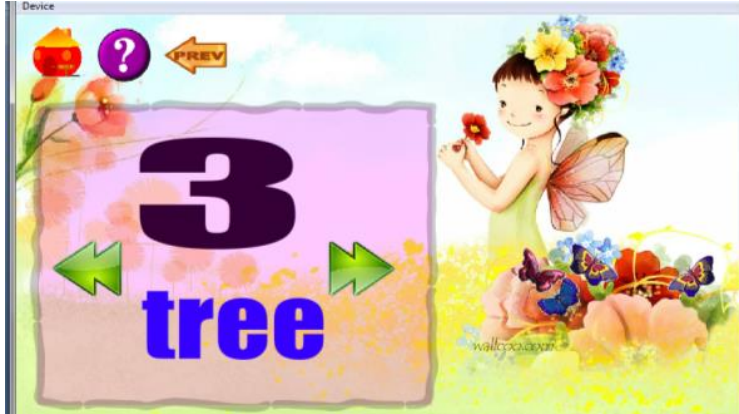

Sumber : Hasil Penelitian (2019)

Gambar 9. Tampilan Number

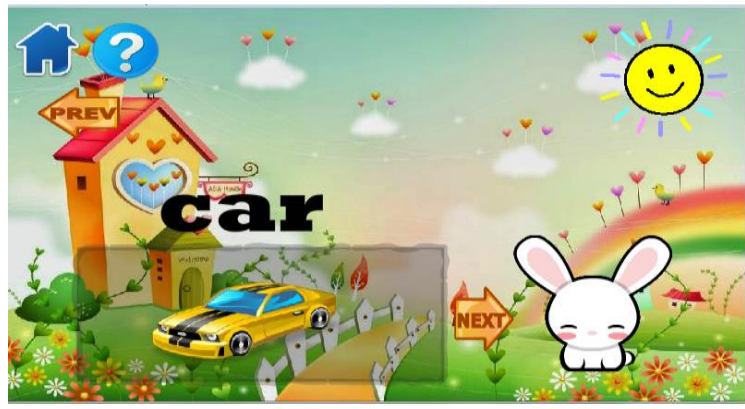

Sumber : Hasil Penelitian (2019)

Gambar 10. Tampilan Transportation

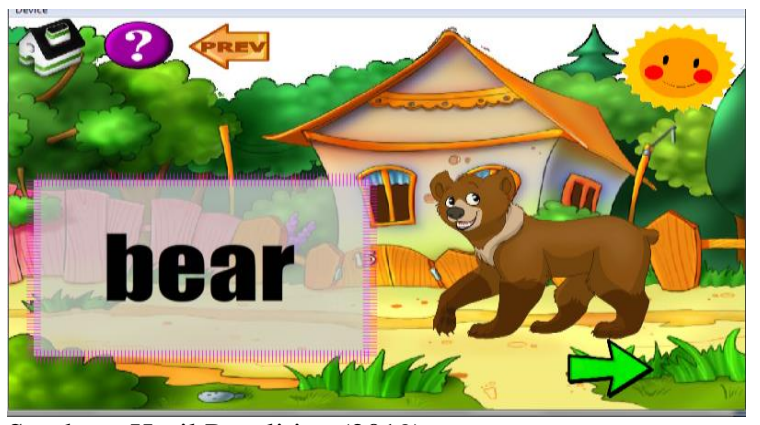

Sumber : Hasil Penelitian (2019)

Gambar 11. Tampilan Animal

\section{Penerapan (Implementation)}

Dalam penelitian ini tahapan dalam implementation atau penerapan meliputi spesifikasi perangkat keras, spesifikasi perangkat lunak, dan pengujian animasi.

a. Spesifikasi Perangkat Keras

Netbook Aspire One 522

CPU AMD Dual - Core Processor C - 50 (1.0

$\mathrm{GHz}$ )

Memory 1 GB DDR3

Battery 6-cell Li-ion

Storage 320 GB HDD

Mouse

Keyboard

b. Spesifikasi Perangkat Lunak

Microsoft Windows 7

Macromedia Flash 8

Adobe Photoshop CS

Adobe Ilustrator CS

Adobe After Effects CS 3

\section{c. Pengujian Animasi}

Aplikasi pembelajaran animasi interktif yang telah dibuat selanjutnya diuji melalui teknik pengujian perangkat lunak yang meliputi white box testing dan black box testing. Pengujian dilakukan untuk memastikan bahwa semua statement pada program telah dieksekusi paling tidak satu kali selama pengujian dan bahwa semua kondisi logis telah diuji.

\section{1) Whitebox Testing}

Dengan menggunakan metode pengujian Whitebox testing akan diperoleh test case sebagai berikut (Pressman, 2010):

a) Menjamin bahwa semua jalur independen dalam sebuah modul telah dieksekusi setidaknya satu kali.

b) Melakukan semua keputusan logis pada sisi benar dan yang salah.

c) Melaksanakan semua loop (putaran) pada batas mereka dan dalam batas-batas operasional mereka.

d) Melakukan struktur data internal untuk memastikan kesahihannya.

Metode pengujian White Box menggunakan struktur kontrol desain prosedural (structural testing) untuk memperoleh test case. Pengujian dilakukan untuk memastikan bahwa semua statement pada program telah dieksekusi paling tidak satu kali selama pengujian dan bahwa semua kondisi logis telah diuji.

Mengukur kompleksitas siklomatis (pengukuran kuantitatif terhadap kompleksitas logis suatu program) dapat diperoleh dengan perhitungan seperti $\mathrm{V}(\mathrm{G})=\mathrm{E}-\mathrm{N}+2$ dimana $\mathrm{E}=\mathrm{Jumlah}$ edge grafik alir yang ditandakan dengan gambar panah, dan $\mathrm{N}=\mathrm{Jumlah}$ simpul grafik alir yang ditandakan dengan gambar lingkaran. 


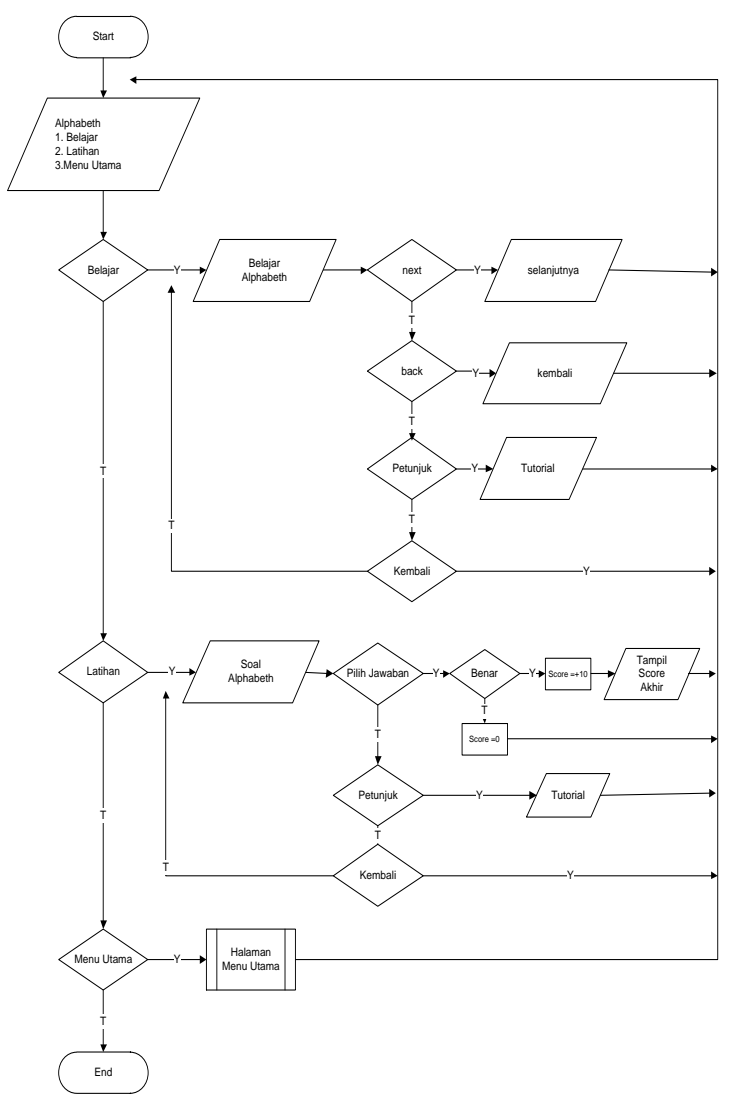

Sumber : Hasil Penelitian (2019)

Gambar 12. Bagan Alir Alphabeth

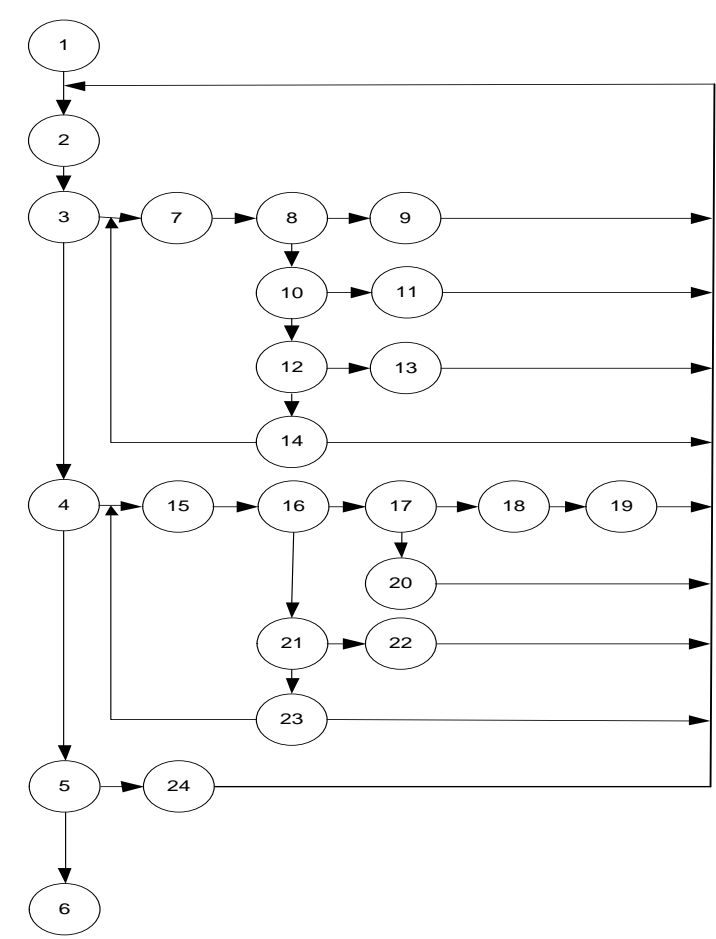

Sumber : Hasil Penelitian (2019)

Gambar 13. Grafik Alir Alphabeth

Sehingga kompleksitas siklomatisnya $\quad \mathrm{V}(\mathrm{G})=34$ $24+2=12$. Terdapat 12 jalur basic path yang dihasilkan dari jalur independent secara linier, yaitu:

$1-2-3-7-8-9$

$1-2-3-7-8-10-11$

$1-2-3-7-8-10-12-13$

$1-2-3-7-8-10-12-14-2$

$1-2-3-7-8-10-12-14-7$

1-2-3-4-15-16-17-18-19

$1-2-3-4-15-16-17-20$

$1-2-3-4-15-16-21-22$

$1-2-3-4-15-16-21-23-2$

$1-2-3-4-15-16-21-23-15$

$1-2-3-4-5-24-2$

$1-2-3-4-5-6$

Ketika aplikasi dijalankan, maka terlihat bahwa salah satu basis set yang dihasilkan adalah 1-2-34-5-6 dan terlihat bahwa simpul telah dieksekusi satu kali. Berdasarkan pengamatan ketentuan tersebut dari segi kelayakan software, sistem ini telah memenuhi syarat.

\section{2) Blackbox Testing}

Black Box Testing (Pengujian Kotak Hitam), juga disebut pengujian perilaku, berfokus pada persyaratan fungsional perangkat lunak. Artinya, teknik pengujian kotak hitam memungkinkan anda untuk membuat beberapa kumpulan kondisi masukan yang sepenuhnya akan melakukan semua kebutuhan fungsional untuk program (Pressman, 2010).

Pengujian ini dilakukan untuk memastikan bahwa suatu masukan akan menjalankan proses yang tepat dan menghasilkan output yang sesuai dengan rancangan.

Tabel 3. Blackbox Testing Tampilan Number

\begin{tabular}{llll}
\hline INPU & PROSES & OUTP & HASI \\
T/EVE & & UT/NE & L \\
$N T$ & & $X T$ & PEN \\
& & STAG & GUJI \\
& & $E$ & AN \\
\hline Tomb & \{ & Numb & Sesua \\
ol & MovieClip(this.root).got & er & i \\
Alpha & oAndPlay(1,"Number"); & & \\
beth & f & & \\
\hline Tomb & \{ & Menu & Sesua \\
ol & MovieClip(this.root).got & Utama & i \\
Menu & oAndPlay(1,"menu"); $\}$ & & \\
Utama & & & \\
\hline Tomb & \{ & Halam & Sesua \\
ol & MovieClip(this.root).got & an & i \\
Belaja & oAndPlay(1,"angka"); $\}$ & Belajar & \\
r & & Numb & \\
& & er & \\
\hline Tomb & Function & Numb & Sesua \\
ol & Fl_ClikToGoNextFrame & er dan & i \\
Numb & (event:MouseEvent):voi & suara & \\
er & d & & \\
& \{ & & \\
\hline
\end{tabular}




\begin{tabular}{|c|c|c|c|}
\hline & \multicolumn{3}{|l|}{$\begin{array}{l}\text { nextFtame }() ; \\
\}\end{array}$} \\
\hline $\begin{array}{l}\text { Petunj } \\
\text { uk }\end{array}$ & $\begin{array}{l}\text { Function } \\
\text { Fl_ClikToGoNextFrame } \\
\text { (event:MouseEvent):voi } \\
\text { d } \\
\{ \\
\text { goToAndStop(54); } \\
\{\end{array}$ & $\begin{array}{l}\text { Petunj } \\
\text { uk }\end{array}$ & $\begin{array}{l}\text { Sesua } \\
\text { i }\end{array}$ \\
\hline $\begin{array}{l}\text { Kemb } \\
\text { ali }\end{array}$ & $\begin{array}{l}\text { Function } \\
\text { Fl_ClikToGoNextFrame } \\
\text { (event:MouseEvent):voi } \\
\text { d } \\
\{ \\
\{ \\
\text { MovieClip(this.root).got } \\
\text { oAndPlay(1,"menu"); }\end{array}$ & $\begin{array}{l}\text { Halam } \\
\text { an } \\
\text { menu }\end{array}$ & $\begin{array}{l}\text { Sesua } \\
\text { i }\end{array}$ \\
\hline $\begin{array}{l}\text { Previe } \\
\mathrm{w}\end{array}$ & $\begin{array}{l}\text { Function } \\
\text { Fl_ClikToGoScene_3(e } \\
\text { vent:MouseEvent):void } \\
\{ \\
\{ \\
\text { MovieClip(this.root).got } \\
\text { oAndPlay(1,"Pilih_Num } \\
\text { ber"); }\}\end{array}$ & $\begin{array}{l}\text { Halam } \\
\text { an } \\
\text { pilihan } \\
\text { belajar } \\
\text { dan } \\
\text { latihan }\end{array}$ & \\
\hline $\begin{array}{l}\text { Tomb } \\
\text { ol } \\
\text { Latiha } \\
n\end{array}$ & $\begin{array}{l}\text { Function } \\
\text { Fl_ClikToGoScene_13( } \\
\text { event:MouseEvent):void } \\
\{ \\
\{ \\
\text { MovieClip(this.root).got } \\
\text { oAndPlay(1,"Soal_Num } \\
\text { ber"); }\end{array}$ & $\begin{array}{l}\text { Latiha } \\
\mathrm{n} \\
\text { Numb } \\
\text { er }\end{array}$ & $\begin{array}{l}\text { Sesua } \\
\mathrm{i}\end{array}$ \\
\hline $\begin{array}{l}\text { Menja } \\
\text { wab } \\
\text { soal }\end{array}$ & $\begin{array}{l}\{ \\
\text { Soal2.visible=false; } \\
\text { Jll.visible=false; } \\
\text { Jlr.visible=false; } \\
\text { Salah.visible=false; } \\
\text { Benar.visible=true; } \\
\text { Soalberikutnya.visible=t } \\
\text { rue; } \\
\text { Skor=skor+10; } \\
\{\end{array}$ & $\begin{array}{l}\text { Score } \\
\text { Nilai }\end{array}$ & $\begin{array}{l}\text { Sesua } \\
\mathrm{i}\end{array}$ \\
\hline Sumber & Hasil Penelitian (2019) & & \\
\hline $\begin{array}{l}\text { 4. Eval } \\
\text { Dalam } \\
\text { perhitur } \\
\text { kuesion } \\
\text { yang di } \\
\text { mengis } \\
\text { kepada } \\
\text { setiap l } \\
\text { Hasil } \\
\text { pembel } \\
\text { adalah }\end{array}$ & $\begin{array}{l}\text { lasi (Evaluation) } \\
\text { tahapan evaluasi dil } \\
\text { gan data yang didapat dar } \\
\text { r. Kuesioner dibagikan } \mathrm{k} \\
\text { lampingi oleh orang tuanya } \\
\text { kuesioner tersebut kue } \\
10 \text { anak berusia } 3 \text { sampa } \\
\text { mbar kuesioner terdiri dari } \\
\text { erhitungan kuesioner a } \\
\text { jaran bahasa inggris untu } \\
\text { bagai berikut: }\end{array}$ & $\begin{array}{l}\text { kukan } \\
\text { hasil pe } \\
\text { oada par } \\
\text { untuk m } \\
\text { ioner c } \\
5 \text { tahun } \\
\text { pertany } \\
\text { masi i } \\
\text { anak u }\end{array}$ & $\begin{array}{l}\text { melalui } \\
\text { gisisan } \\
\text { siswa } \\
\text { mbantu } \\
\text { berikan } \\
\text { dimana } \\
\text { an. } \\
\text { terkatif } \\
\text { ia dini }\end{array}$ \\
\hline
\end{tabular}

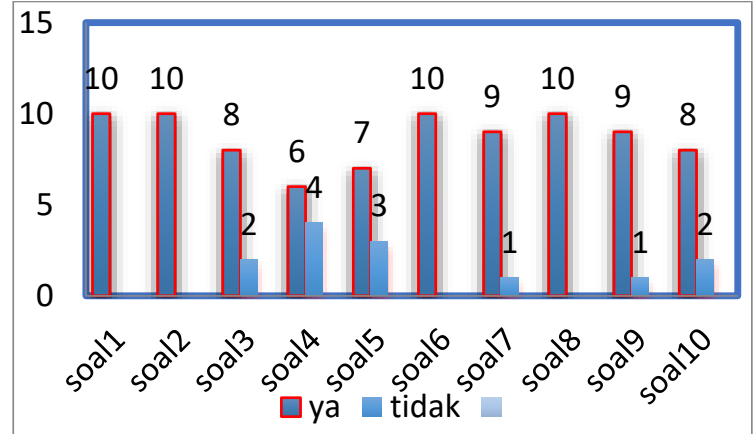

Sumber : Hasil Penelitian (2019)

Gambar 14. Hasil Grafik Kuesioner

Dari kuesioner pada gambar 14 diperoleh hasil perhitungan presentase $87 \%$ menjawab ya dan $13 \%$ menjawab tidak. Sehingga dapat diambil kesimpulan bahwa ank-anak tersebut dapat dengan mudah menggunakan aplikasi ini, menjadi lebih tertarik belajar bahasa inggris dan dapat digunakan sebagai alat bantu yang dapat membantu anak-anak dalam belajar bahasa inggris sehingga belajar jadi tidak membosankan.

\section{KESIMPULAN}

Berdasarkan analisis dan penelitian yang telah lakukan, maka dapat diambil kesimpulan bahwa dengan adanya animasi interakti pembelajaran bahasa inggris dapat membantu guru dan anak-anak dalam proses belajar bahasa inggris, dengan diterapkannya animasi interaktif pembelajaran bahasa inggris dapat membantu anak-anak dalam mengingat pelajaran sehingga proses belajar dan mengajar menjadi efektif dan menyenangkan, dan animasi interaktif pembelajaran bahasa inggris ini dapat di akses dimana saja dan kapan saja dizaman yang teknologinya semakin berkembang seperti saat ini.

Namun, animasi interaktif ini masih sangat sederhana, sehingga sangat mungkin untuk dikembangkan agar menjadi lebih baik lagi. Untuk pembuatan animasi interaktif ini sebaiknya dilakukan sebuah pengujian yang berulang-ulang agar dapat memenuhi kekurangan dan mengetahui baik atau tidaknya program ini, dalam penggunaan animasi ini sebaiknya diawasi oleh orang dewasa yang dapat mengontrol proses belajar sehingga proses pembelajaran semakin baik, dan juga dalam perancangan aplikasi ini diperlukan perancangan yang matang agar lebih kreatif dalam menentukan metode pengenalan dan pengetahuan sehingga animasi interaktif ini dapat dikembangkan sesuai dengan perkembangan teknologi dan informasi yang lebih baru. 


\section{REFERENSI}

Ariyati, S., \& Misriati, T. (2016). Perancangan animasi interaktif pembelajaran asmaul husna. Jurnal Teknik Komputer, II(1), 116-121.

Pressman, R. S. (2010). Rekayasa Perangkat LunakBuku Satu, Pendekatan Praktisi (Edisi 7). Yogyakarta: Andi.

Sugiyono. (2013). Metodelogi Penelitian Kuantitatif, Kualitatif Dan R\&D. Bandung: Alfabeta.

Sugiyono. (2015). Metode Penelitian Kombinasi (Mix Methods). Bandung: Alfabeta.

Wijayanto, R. (2014). PERANCANGAN ANIMASI INTERAKTIF PEMBELAJARAN BAHASA INGGRIS UNTUK KELAS 2 PADA MI
NURUL FALAH CIATER. Jurnal Evolusi, II (1), 1-11.

\section{PROFIL PENULIS}

Penulis bernama Mia Rosmiati, M.Kom. Pada tahun 2011 lulus dari Program Strata Satu (S1) Program Studi Sistem Informasi STMIK Nusa Mandiri Jakarta. Tahun 2015 lulus dari Program Strata Dua (S2) Program Studi Magister Ilmu Komputer STMIK Nusa Mandiri Jakarta. Tahun 2016 sudah memiliki Jabatan Fungsional Dosen Asisten Ahli. Sampai saat ini aktif mengikuti seminar dan menulis artikel ilmiah di beberapa junal nasional, di antaranya Jurnal Techno STMIK Nusa Mandiri Jakarta, dan Jurnal Paradigma Universitas Bina Sarana Informatika, dan Jurnal Teknik Komputer Universitas Bina Sarana Informatika. 